\title{
Mitigation of clayey soil compaction managed under no-tillage
}

\author{
Márcio Renato Nunes a,*, José Eloir Denardin ${ }^{\mathrm{b}}$, Eloy Antonio Pauletto ${ }^{\mathrm{c}}$, \\ Antonio Faganello ${ }^{\mathrm{b}}$, Luiz Fernando Spinelli Pinto ${ }^{\mathrm{c}}$ \\ a University of São Paulo, "Luiz de Queiroz" College of Agriculture, Avenida Pádua Dias, 11, CEP 13418-900 Piracicaba, São Paulo, Brazil \\ ${ }^{\mathrm{b}}$ Embrapa Trigo, Rodovia BR 285, km 294, P.O. Box 451, CEP 99001-970 Passo Fundo, Rio Grande do Sul, Brazil \\ ${ }^{\mathrm{c}}$ Federal University of Pelotas, Department of Soil Science, Campus Universitário s/n, P.O. Box 354, CEP 96010-900 Pelotas, Rio Grande do Sul, Brazil
}

\section{A R T I C LE IN F O}

\section{Article history:}

Received 12 August 2014

Received in revised form 10 December 2014

Accepted 11 December 2014

\section{Keywords:}

No-till seeder

Root system

Soil physical properties

Development of corn plants

Fixed shank openers

\begin{abstract}
A B S T R A C T
Soil compaction has always been a problem to the agricultural productivity, mainly in clayey soils under the no-tillage (NT). Alternatives to mitigate this problem are necessary. The aim of this study was to evaluate the effect of seeder equipped with fixed shanks openers, working at three depths, in a Ferralic Nitisol (Rhodic), under NT on the mitigation of soil compaction and corn (Zea mays L.) plant development. The test comprised three treatments regarding the depth at which the shank openers of a seeder used to sow corn worked: openers reaching up to $0.05 \mathrm{~m}$; openers reaching up to $0.07 \mathrm{~m}$; and openers reaching up to $0.17 \mathrm{~m}$. The effect of these treatments was evaluated in relation to the determination of soil physical parameters, and corn plant parameters. The use of a seeder equipped with fixed shanks openers up to $0.17 \mathrm{~m}$ depth caused an increase in soil macroporosity and total porosity, and a decrease in soil bulk density, soil resistance to penetration and degree of compactness in the layer between 0.07 and $0.17 \mathrm{~m}$. The improved physical conditions of the soil in this layer led to a further development of the root system of plants in greater depth, and consequently to a better development of corn plants with higher stalk diameter, root density and root length. The use of a seeder equipped with fixed shanks openers working up to $0.17 \mathrm{~m}$ depth, therefore, promoted physical improvement to the soil, favoring the development of corn plants, and presenting potential to mitigate the compaction of clayey soils under NT.
\end{abstract}

(c) 2014 Elsevier B.V. All rights reserved.

\section{Introduction}

The no-tillage (NT), adopted in more than 100 million hectares in the world, results in economic and environmental benefits (Derpsch et al., 2010). The compaction of soils managed under NT, however, has been frequently reported (Hubbard et al., 1994; Hamza and Anderson, 2005; Raper et al., 2005; Batey, 2009; Reichert et al., 2009; Nunes et al., 2014a). Soil compaction limits root development of plants (Bengough et al., 2011; Lipiec et al., 2012; Nosalewicz and Lipiec, 2014) which impairs the uptake of water and nutrients (Batey and McKenzie, 2006), consequently causing a decrease in crop yield (Hamza and Anderson, 2005; Chen and Weil, 2011). Alternatives to mitigate this problem are therefore necessary and of worldwide concern.

\footnotetext{
* Corresponding author. Tel.: +55 19999229218.

E-mail addresses: marcio_r_nunes@yahoo.com.br, marcio_r_nunes@usp.com (M.R. Nunes), denardin@cnpt.embrapa.br (J.E. Denardin), pauletto@ufpel.edu.br (E.A. Pauletto), afaganel@cnpt.embrapa.br (A. Faganello), lfspin@ufpel.edu.br (L.F.S. Pinto).
}

The profile of soils under NT, mainly clayey soils, typically has a layer, at around 0.07 and $0.20 \mathrm{~m}$ deep, characterized by high soil bulk density, high mechanical resistance to penetration of root and low soil permeability to air and water (Shipitalo and Protz, 1987; Reichert et al., 2009; Lahmar 2010; Farooq et al., 2011; Nunes et al., 2014a). These conditions concentrate the crop root system in the topsoil layer, at around 0.0-0.07 m (Reichert et al., 2009; Nunes et al., 2014b). The compacted soil layer $(0.07-0.20 \mathrm{~m})$ limits the water extraction from the subsoil to the topsoil layer (Lipiec et al., 2003), where the root system is concentrated leading to the water stress, even in short periods of drought. Buttery et al. (1998) argue that smaller root penetration of compacted soil aggravates the effects of drought and reduces the productivity of soybean (Glycine $\max ($ L.) Merrill). In Brazil subtropical humid climate region, crop losses are frequent, and, according to Denardin et al. (2008), these are associated to soil compaction under NT.

In general, seeders used in NT are equipped with disk and shanks, in order to open the furrow and lay fertilizer in the soil (Altikat and Celik, 2011; Casão Junior et al. 2012). These openers reach up to around $0.10 \mathrm{~m}$ deep, promoting local relief of the soil superficial compaction (Baker, 1976; C haudhuri, 2001 Ros et al., 2011; Silva et al., 2014a). Lower soil density (Kaspar et al., 1991; 
Damora and Pandey, 1995), lower soil resistance to penetration (Veiga et al., 2007) and better soil structure (Tormena et al., 2008; Silva et al., 2014a) have been reported in the row compared with the interrow on soil under NT. This working depth $(0.10 \mathrm{~m})$, however, is not enough to break the compacted layer existing in the soil under NT. Greater depth of action of the planter seeder could therefore be an alternative to break the layer of compacted soil and promote better physical conditions for root development of agricultural crops in soils managed under NT.

In a recent study, Nunes et al. (2014a) observed that the use of seeder equipped with fixed shanks openers working at $0.17 \mathrm{~m}$ depth might relieve soil compaction, in the subsurface, in areas under NT. Hypothetically, this would enable the deepening of the crop species root system, thus, decreasing risks of crop losses due to water stress. Nunes et al. (2014a), however, only assessed the effects of the employment of this planter seeder on soil attributes. Therefore, more detailed studies to assess the development of crops sowed with this type of disruptive element soil seeder need to be performed.

The hypotheses presented in this paper are: (i) the use of seeders equipped with fixed shanks openers, working at the compacted layer depth, improve soil physical root growth conditions on clayey soil compaction under NT; and (ii) a seeder equipped with fixed shanks openers, working at the compacted layer depth, improve the development, in depth, of the corn root system. The objective of this study was to evaluate the effect of a seeder equipped with fixed shanks openers, working at three depths, in a Ferralic Nitisol (Rhodic) under NT, on the mitigation of soil compaction and the development of corn plants.

\section{Material and methods}

\subsection{Experimental design and area}

The study was carried out at the Embrapa Trigo Experimental Field, in Passo Fundo, Rio Grande do Sul, Brazil $\left(28^{\circ} 11^{\prime} 20^{\prime \prime} \mathrm{S}\right.$, $52^{\circ} 19^{\prime} 62^{\prime \prime} \mathrm{W}$ ), in a Ferralic Nitisol (Rhodic) (USDA, 2012) situated at $691 \mathrm{~m}$ altitude. The experimental area soil physical characterization, the water dispersed clay (Gee and Or, 2002), and the soil organic carbon (determined through the Walkley-Black method), is found in Table 1 . The local relief is gently undulating with $3 \%$ slopes in the experimental area. The climate, according to the Köppen classification, is Cfa (subtropical humid), with rainfall well distributed throughout the year ranging from 1300 to $1800 \mathrm{~mm}$ year, with higher values in May and June (Nimer, 1989).
Table 1

Physical characterization and organic carbon (OC) of the Ferralic Nitisol (Rhodic) used in the study on mitigation of clayey soil compaction under no-till.

\begin{tabular}{lllllll}
\hline $\begin{array}{l}\text { Layer } \\
(\mathrm{m})\end{array}$ & $\begin{array}{l}\text { Clay } \\
\left(\mathrm{g} \mathrm{kg}^{-1}\right)\end{array}$ & Silt & Sand & WDC & $\begin{array}{l}\mathrm{Pd} \\
\left(\mathrm{kg} \mathrm{m}^{-3}\right)\end{array}$ & $\begin{array}{l}\text { OC } \\
(\%)\end{array}$ \\
\hline $0.00-0.07$ & 595 & 193 & 212 & 310 & 2,680 & 1.91 \\
$0.07-0.17$ & 590 & 201 & 209 & 360 & 2,730 & 1.31 \\
$0.17-0.20$ & 603 & 190 & 207 & 350 & 2,750 & 1.24 \\
$0.20-0.30$ & 663 & 166 & 171 & 420 & 2,730 & 1.17 \\
\hline
\end{tabular}

WDC: water dispersed clay; Pd: particle density.

The experimental area had been under NT for over ten years, in a crop production model comprised by the succession of soybean (Glycine $\max (\mathrm{L}$.$) Merrill) in the summer and wheat (Triticum$ aestivum $\mathrm{L}$.) in the winter. The soil in this area clearly presented physical degradation of the layer between 0.07 and $0.20 \mathrm{~m}$ depth, revealed in an expeditious evaluation performed in the field by the method of the cultural profile (Tavares Filho et al., 1999), in $0.3 \mathrm{~m}$ deep and $0.3 \mathrm{~m}$ wide soil pits.

The field experiment was designed in randomized blocks, with four replications and three treatments, resulting in 12 plots with dimensions of $8 \times 6 \mathrm{~m}$ each $\left(48 \mathrm{~m}^{2}\right)$. The species grown throughout the test (September 2009 to February 2012) were: corn (Zea mays L.), from September 2009 to February 2010; wheat, from June to November 2010; soybean from November 2010 to March 2011; rye (Secale cereale L.), from April to September 2011; and corn, from September 2011 to February 2012. In this period, the summer crops were sown with seeder (Fig. 1a) equipped with a fixed shank opener (Fig. 1b), in order to produce the furrow and also lay the fertilizer into the soil. The treatments comprised the opener depth as follows: $\mathrm{T} 5=$ openers reaching up to $0.05 \mathrm{~m}$; $\mathrm{T} 7=$ openers reaching up to $0.07 \mathrm{~m}$; and $\mathrm{T} 17=$ openers reaching up to $0.17 \mathrm{~m}$. The treatments T5 and T7 represented the depth of action of soil openers typically employed in the subtropical humid climate region in Brazil.

The weight of the seed drill used in this study was approximately $2800 \mathrm{~kg}$ while the weight of the tractor used to pull the seeder was around $5000 \mathrm{~kg}$. The speed of the machine for sowing operations was $1.4 \mathrm{~m} \mathrm{~s}^{-1}$. The seeder operated with three lines, spaced by $0.60 \mathrm{~m}$, for corn sowing (Fig. 1a), and with five lines, spaced by $0.45 \mathrm{~m}$, soybean sowing. The row direction was the same in all crops, however, the position of the lines varied from one crop to another. The width of the shank that equipped the seeder for sowing soybean and corn was $15 \mathrm{~mm}$. A set of screws (Fig. 1b) allowed the depth of operation of the shank to adjust to the desired
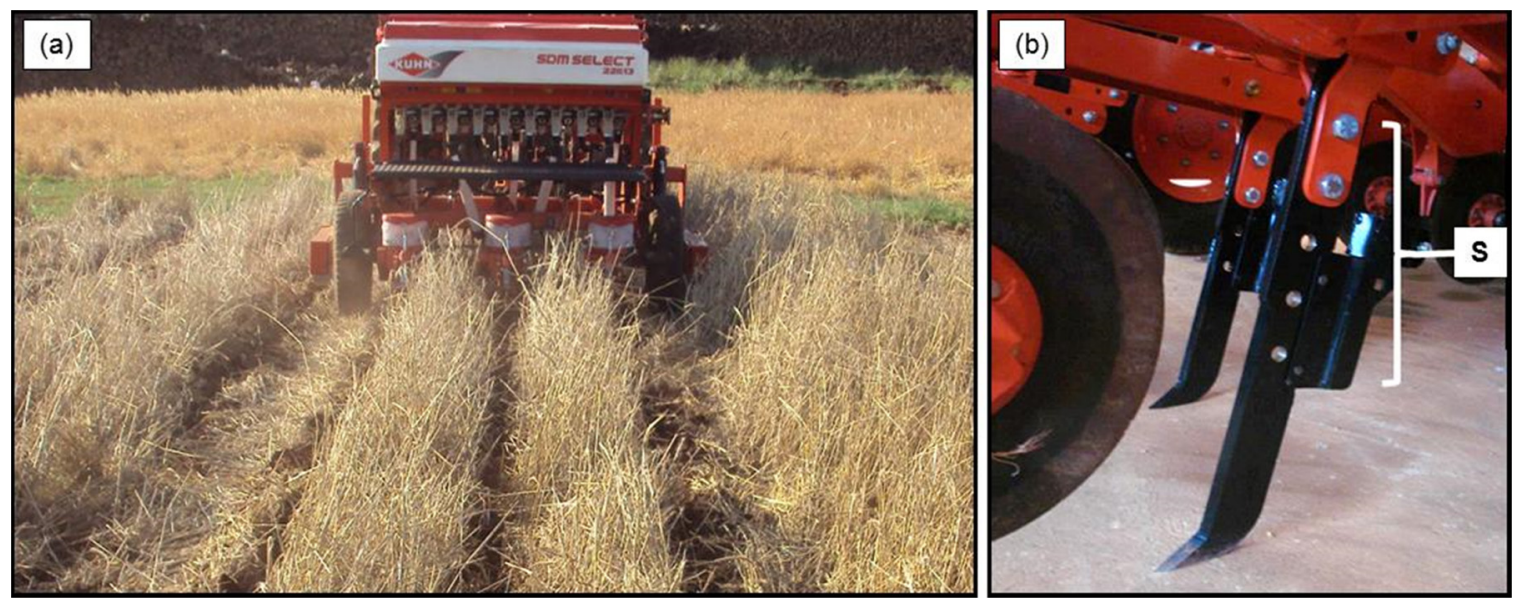

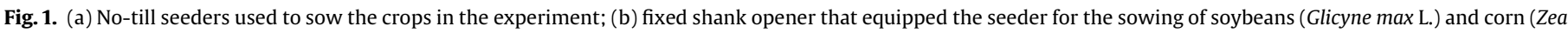
mays L.), and, in detail (S), the set of screws that allowed to adjust the desired depth of operation of the shank. 


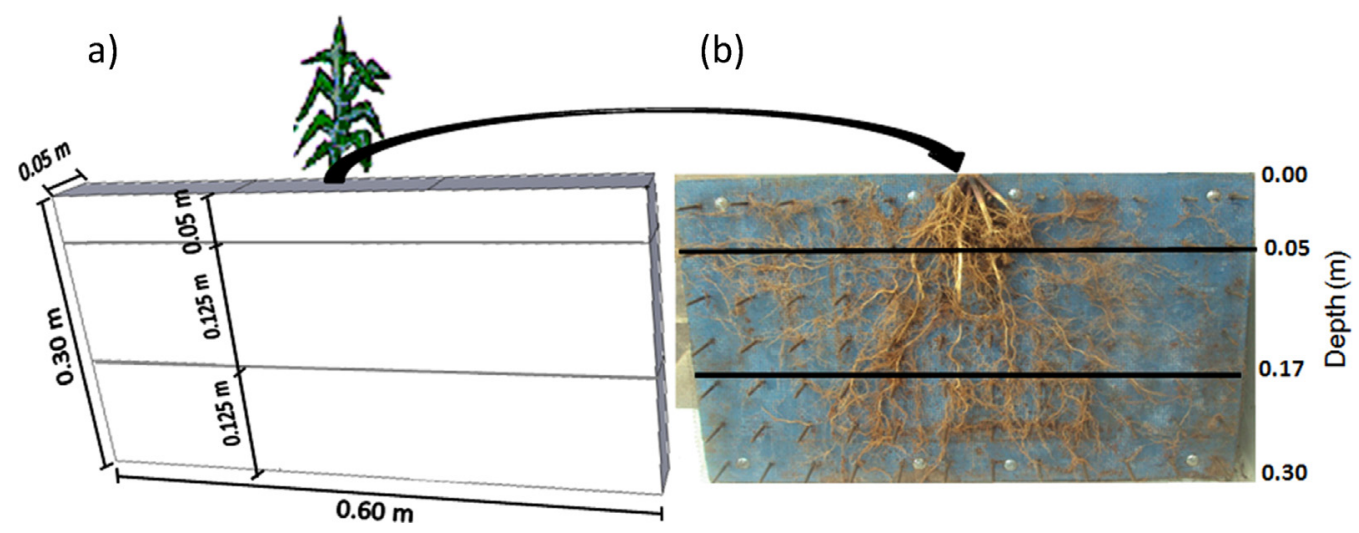

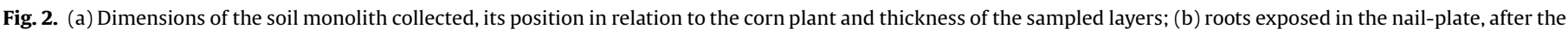
dispersion and soil removal, showing the depths at which roots were subdivided.

depth for the studied treatments. Crops of wheat and rye were sown with row spacing of $0.17 \mathrm{~m}$, with the same planter, however, operating without the planter chisel. Seeding operations were conducted when the soil moisture content was close to the point of friability. During the study, machinery traffic in the experimental area was restricted to the period of crop sowing.

\subsection{Sampling and evaluations}

In December 2011, in the corn R3 phenological stage (Ritchie and Hanway, 1993), the plant stalk diameter and the root system were evaluated. The stalk diameter was evaluated from the second internode above the soil, in 10 corn plants randomly positioned in the central line of each experimental unit. The root system was evaluated through the nail-plate technique (Bohm, 1979). The nailplate used was $0.60 \mathrm{~m}$ wide, $0.30 \mathrm{~m}$ high and $0.05 \mathrm{~m}$ thick (Fig. 2), determining the collection with $9 \mathrm{dm}^{3}$ of a soil and root monolith, in each experimental unit. After the dispersion and soil removal from the monoliths, the root system present in each monolith was divided into three layers: $0.0-0.05 \mathrm{~m} ; 0.05-0.17 \mathrm{~m} ; 0.17-0.30 \mathrm{~m}$ (Fig. 2).

The roots contained in each layer were placed in a container with a small amount of water, organized in a way that they did not overlap in order to be submitted to digitalization with a HP Scanjet 3570C scanner, with resolution of $450 \mathrm{dpi}$. The root length was quantified with the software Safira (Jorge and Rodrigues, 2008). Later on, the roots were dried in oven at $65^{\circ} \mathrm{C}$, for $72 \mathrm{~h}$, the dry matter mass was evaluated in a $0.0001 \mathrm{~g}$ precision scale. The root density, in kilograms per soil cubic meters, was estimated through the ratio between the root dry matter mass and the soil volume in each layer. The root length, in meters per soil cubic meters, was estimated through ratio between the root length and the soil volume in each layer.

In March 2012, after the corn harvest, in the experimental units corresponding to treatment T1, pits, measuring $0.60 \mathrm{~m}$ wide and $0.30 \mathrm{~m}$ deep, were opened transversally to the sowing lines, in order to describe the soil cultural profile (Tavares Filho et al., 1999). This technique identified three distinct layers of soil: Layer L (surface layer), from 0.0 to $0.07 \mathrm{~m}$, characterized by soil volume comprised of aggregates of varied sizes, porosity visible to the naked eye, and high presence of roots; Layer $\mathrm{C} \Delta \mu, 0.07-0.20 \mathrm{~m}$ layer, characterized by massive soil structure, without porosity visible to the naked eye, and with lower presence of roots in relation to the surface layer; and layer $\mathrm{F} \Delta \mu, 0.20-0.30 \mathrm{~m}$, characterized by the soil with a polyhedric blocky typical Ferralic Nitisol (Rhodic) structure (Fig. 3a). Similar pits were opened in the remaining experimental units to collect the soil samples, with minimal disturbed structure, in stainless steel cylinders with $48 \mathrm{~mm}$ diameter and $30 \mathrm{~mm}$ height. The samples were collected in the position corresponding to the sowing line, following the characterization of layers described by the cultural profile technique applied in T5, at four depths, due to the remaining effect of the seeders openers used in the corn sowing reaching up to $0.17 \mathrm{~m}$ deep (Fig. $3 \mathrm{~b}$ ). Thus, the sampled layers were: $0.0-0.07 \mathrm{~m}$; 0.07-0.17 m; 0.17-0.20 m; and 0.20-0.30 m (Fig. 3).

In each experimental unit, six samples by soil layer were collected. Three of these samples were used to determine the soil resistance to penetration. The remaining soil samples were used
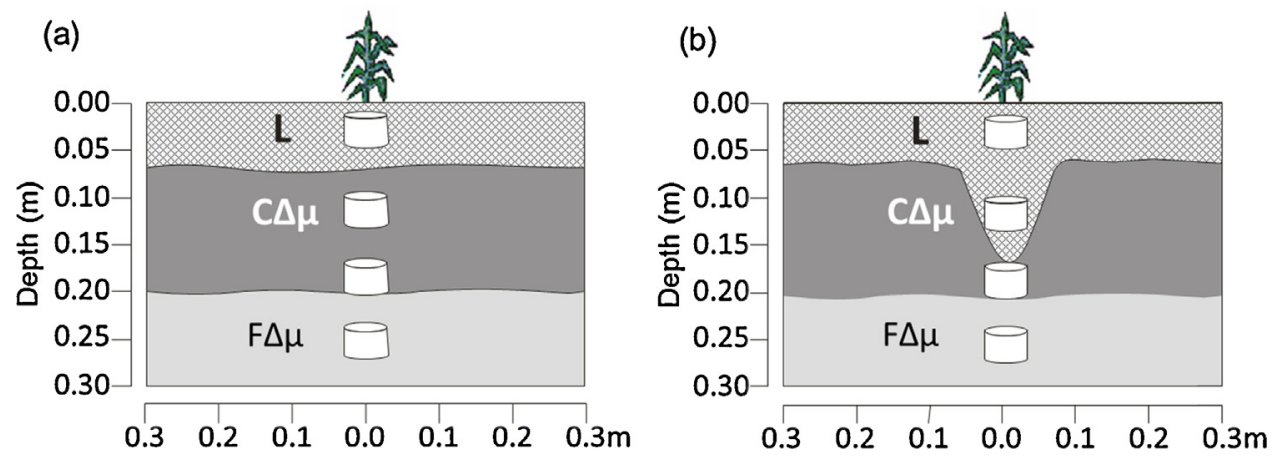

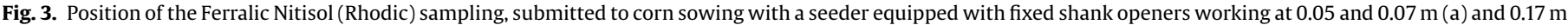

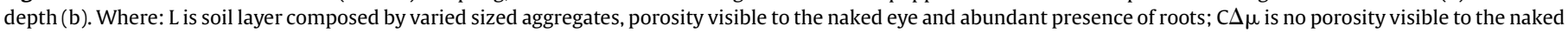
eye and lower presence of roots in relation to the superficial layer L; F $\Delta \mu$ is soil layer with with a polyhedric blocky typical of a Ferralic Nitisol (Rhodic). 
to determine the following soil physical properties: macroporosity, total porosity, bulk density and degree of compactness. The samples were saturated through capillarity, for $48 \mathrm{~h}$, balanced on the tension table at $-6 \mathrm{kPa}$, obtaining the soil water content for this tension. Subsequently, the same samples were saturated again, equilibrated at $-10 \mathrm{kPa}$ and subjected to uniaxial compression test.

The uniaxial compression test was carried out, in each sample, through the sequential application of pressures 25, 50, 100, 200, 400,800 and $1600 \mathrm{kPa}$, to the samples water tension balanced at $-10 \mathrm{kPa}$. Then, the samples were dried in oven at $105^{\circ} \mathrm{C}$, for $24 \mathrm{~h}$ and the soil bulk density calculated. The soil degree of compactness was calculated, taking as reference the bulk density obtained after 200,400 and $800 \mathrm{kPa}$ pressure was applied, employing the expression (Reichert et al., 2009):

$\mathrm{Dc}(\%)=\frac{\mathrm{BD}}{\text { BDref }} \times 100$

where Dc is the soil degree of compactness; BD is the soil bulk density at the time of the collection, and BDref is the soil bulk density after 200, 400 and $800 \mathrm{kPa}$ pressure was applied.

Macroporosity $(\varnothing \geq 0.05 \mathrm{~mm})$, total porosity and soil bulk density were determined according to Donagema et al. (2011).
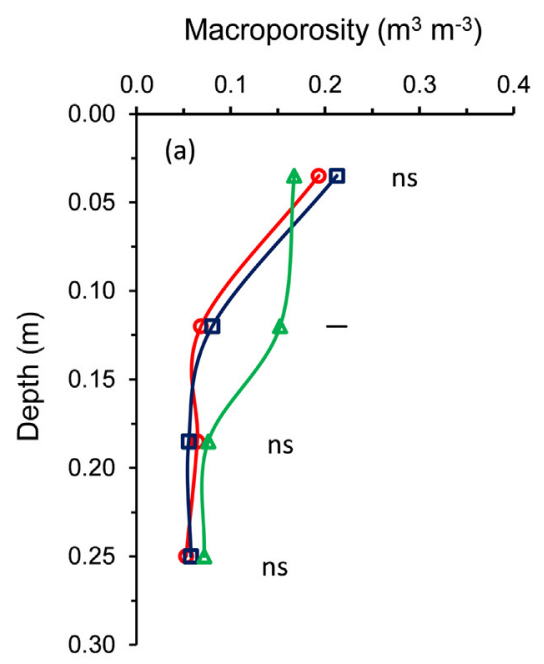

Soil bulk density $\left(\mathrm{g} \mathrm{cm}^{-3}\right)$
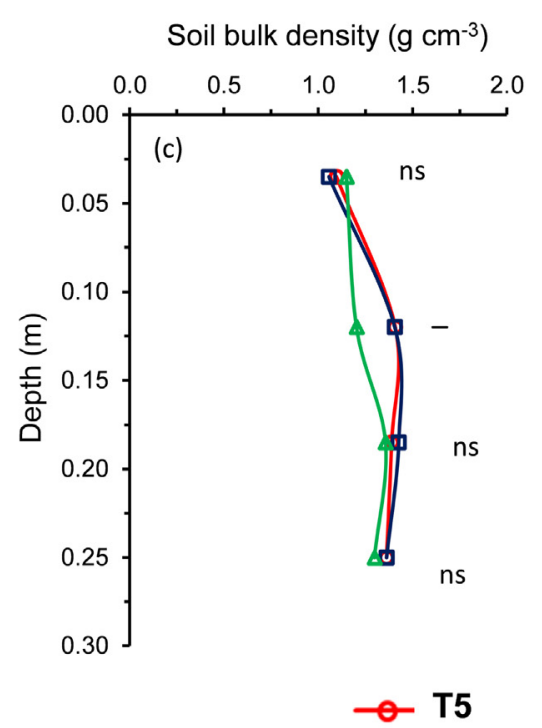

The soil penetration resistance was determined with a benchmounted electronic penetrometer, model MA 933, brand Marconi, equipped with an electronic speed variator, data register system and cone with a semi-angle of $300^{\circ}$ and $3 \mathrm{~mm}$ diameter. The penetration speed was $10 \mathrm{~mm} \mathrm{~min}^{-1}$. The determination of soil penetration resistance was processed in the samples with water tension balanced at $-10 \mathrm{kPa}$. The soil penetration resistance reading obtained from the upper $(3 \mathrm{~mm})$ and lower $(3 \mathrm{~mm})$ parts of the samples were disregarded, only taking into consideration the readings of the $24 \mathrm{~mm}$ in the center of each sample.

\subsection{Statistical analysis}

The effect of the seeders openers working at different depths, in the soil physical properties macroporosity, total porosity and penetration resistance and the root dry matter mass, density and corn plant root length was evaluated through variance analysis (ANOVA), in each soil layer under study, according to the model: $y_{\mathrm{ij}}=\mu+t_{\mathrm{i}}+b_{\mathrm{j}}+e_{\mathrm{ij}}$ where, $\mu$ is an observation inherent constant; $t_{\mathrm{i}}$ is the i effect treatment; $b_{\mathrm{j}}$ is the effect of block $\mathrm{j}$; and $e_{\mathrm{ij}}$ is the error in the plot $i$. When significant effect was observed, the treatments average was compared using the Tukey test at $5 \%$ probability. In
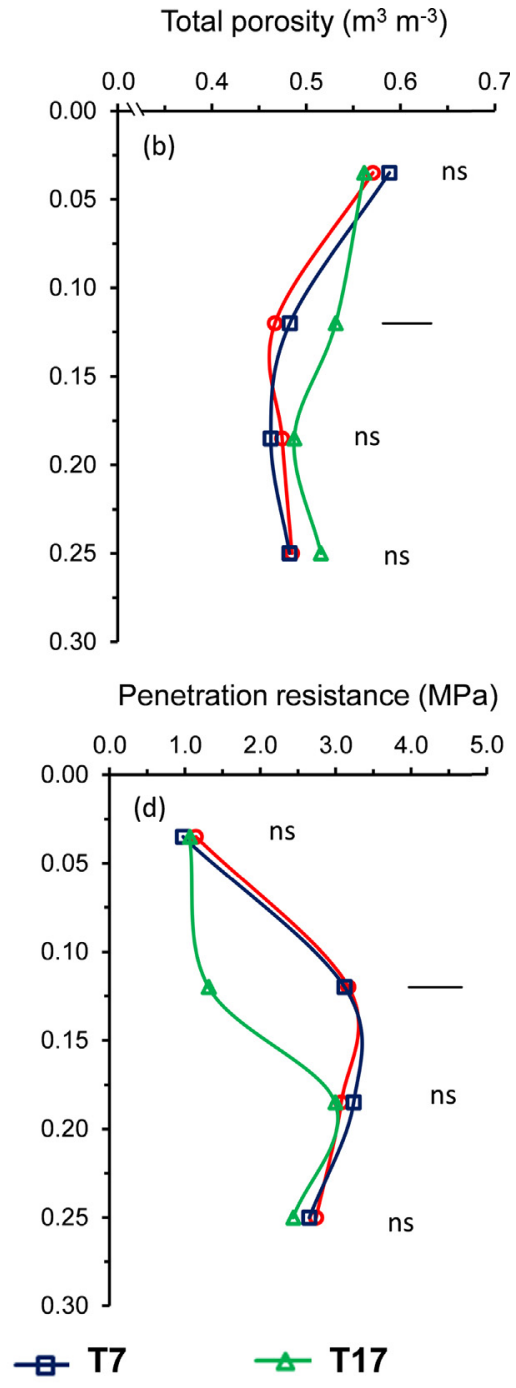

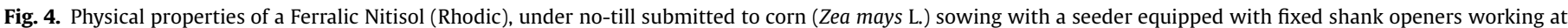

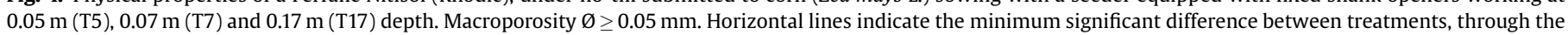
Tukey test at $5 \%$ probability and ns represent the absence of statistical significance. 
relation to the degree of compactness, in the 0.07-0.17 m layer and the corn plant stalk diameter, the standard deviation was calculated in relation to the average for each level of the factor under study.

\section{Results and discussion}

\subsection{Soil physical properties}

The soil physical property values, macroporosity, total porosity, soil resistance to penetration and soil bulk density (Fig. 4), in $\mathrm{T} 5$ and T7, evidenced that the soil was physically degraded. In the 0.07 and $0.20 \mathrm{~m}$ layer, the soil presented high soil resistance to penetration (3.0 MPa) and high soil bulk density values $(1.4 \mathrm{~g}$ $\mathrm{cm}^{-3}$ ), as well as macroporosity below $0.08 \mathrm{~m}^{3} \mathrm{~m}^{-3}$. In clayey soils, this physical condition affects the development of agricultural crops (Tormena et al., 1999). On the other hand, in the topsoil layer $(0.0-0.07 \mathrm{~m})$, the macroporosity was close to $0.20 \mathrm{~m}^{3} \mathrm{~m}^{-3}$, and the penetration resistance and soil bulk density values were lower than those obtained in the subsurface layer. Only in the first few centimeters of the soil profile, therefore, there were favorable physical conditions to the crop root development. This fact is in accordance with Veiga et al. (2007), who pointed out that in the subtropical humid region in Brazil, the soil under NT presents a compacted subsurface layer.

In areas under NT, the intense machine traffic, along with low amounts of soil organic matter, promote soil compaction (Soane, 1990; Veiga et al., 2007) up to approximately $0.20 \mathrm{~m}$ depth. In the topsoil layer (0.0-0.07 m), however, due to soil wet and dry cycles, which influence its aggregation (Horn and Peth, 2009; Silva et al., $2014 \mathrm{~b}$ ), and the action of the coulters and shanks that equip the notill seeders normally used, the compaction is not observed (Fig. 4). Several authors state that the local action of openers which equip the no-till seeders provides improvement to the topsoil layer under NT (Baker, 1976; Kaspar et al., 1991; Veiga et al., 2007; Altikat and Celik 2011; Ros et al., 2011; Nunes et al., 2014a; Silva et al., 2014a). According to Genro Junior et al. (2004), during the winter crop implementation, in rows $0.17 \mathrm{~m}$ wide, there is movement of approximately $30 \%$ of the soil in the layer between 0.0 and $0.05 \mathrm{~m}$, which, together with the movement carried out during the sowing of summer crops, result in a great volume of mobilized soil in the topsoil layer.

In our study, the use of a seeder equipped with fixed shanks openers working at $0.17 \mathrm{~m}$ depth (T17) promoted an increase in macroporosity and total porosity and decrease in the soil resistance to penetration and soil bulk density in the layer between 0.07 and $0.17 \mathrm{~m}$, when compared with T5 and T7 (Fig. 4). Therefore, the use of a seeder equipped with a shanks opener working at the level of the compacted layer, has the potential to mitigate the soil subsurface layer compaction under NT. This perception confirms results obtained by Baker (1976),Damora and Pandey (1995), Ros et al. (2011) and Nunes et al. (2014a), that the depth increase in the seeders shanks openers working during the sowing of crops, reduces soil compaction. According to Chaudhuri (2001), shank type soil breakers promotes better soil physical conditions, as compared with disc-like breakers, providing better performance in regard to the rate of emergence of plants.

The effect of the NT seeder equipped with fixed shanks openers on the soil structure is even more evident when the soil degree of compactness is observed in the 0.07-0.17 m layer (Fig. 5). In this layer, the degree of soil compactness was $91 \%$ (BDref $200 \mathrm{kPa}$ ), $88 \%$ (BDref $400 \mathrm{kPa}$ ) e $84 \%$ (BDref $800 \mathrm{kPa}$ ), for T5 treatment; and $91 \%$ (BDref $200 \mathrm{kPa}$ ), 87\% (BDref $400 \mathrm{kPa}$ ) e $82 \%$ (BDref $800 \mathrm{kPa}$ ), for T7 treatment. According to Reichert et al. (2009), in soils with clay content between 339 and $721 \mathrm{~g} \mathrm{~kg}^{-1}$, degree of soil compactness of $88 \%$ (BDref $200 \mathrm{kPa}$ ), $84 \%$ (BDref $400 \mathrm{kPa}$ ) e $80 \%$ (BDref $800 \mathrm{kPa}$ ) is

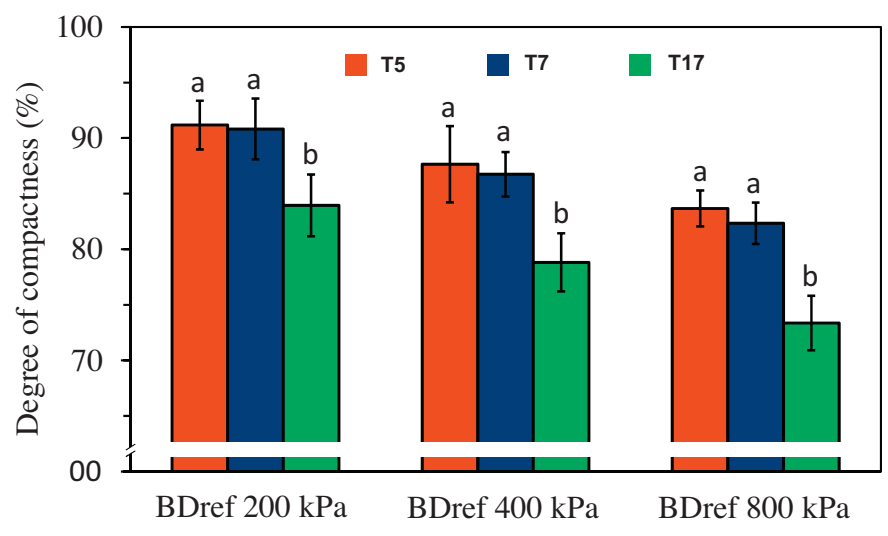

Fig. 5. Degree of compactness of a Ferralic Nitisol (Rhodic), under no-till in the layer 0.07-0.17 m, submitted to corn (Zea mays L.) sowing with a seeder equipped with fixed shank openers working at $0.05 \mathrm{~m}$ (T5), $0.07 \mathrm{~m}$ (T7) and $0.17 \mathrm{~m}$ (T17) depth, as a function of the reference bulk density (BDref) obtained after the application of pressures $200 \mathrm{kPa}, 400 \mathrm{kPa}$ and $800 \mathrm{kPa}$. Vertical bars represent the standard deviation in relation to the average. The same letter, in the same BDref, not differs among themselves regarding the Tukey test at $5 \%$ probability.

critical for the development of agricultural crops. The high degree of soil compactness in the $0.07-0.17$ m layer thus indicates that the soil managed under NT is physically degraded.

The use of a seeder equipped with fixed shanks openers working at $0.17 \mathrm{~m}$ depth reduced the soil degree of compactness in the 0.07-0.17 $\mathrm{m}$ layer, showing values equal to $83 \%$ (BDref $200 \mathrm{kPa}$ ), $78 \%$ (BDref $400 \mathrm{kPa}$ ) and $73 \%$ (BDref $800 \mathrm{kPa}$ ), thus below the values considered critical by Reichert et al. (2009). According to Suzuki et al. (2013), the decrease in the soil degree of compactness results in linear reduction of penetration resistance and linear increase in the soil macroporosity. Hakansson and Lipiec (2000) emphasize that the degree of compactness is a suitable indicator of changes in the soil physical properties, and even, more useful than the soil bulk density and porosity properties in compaction studies. Therefore, the results regarding soil degree of compactness, in this study, reinforce the thesis that the use of seeders equipped with fixed shanks openers working at $0.17 \mathrm{~m}$ depth provides better physical conditions to the plant root development.

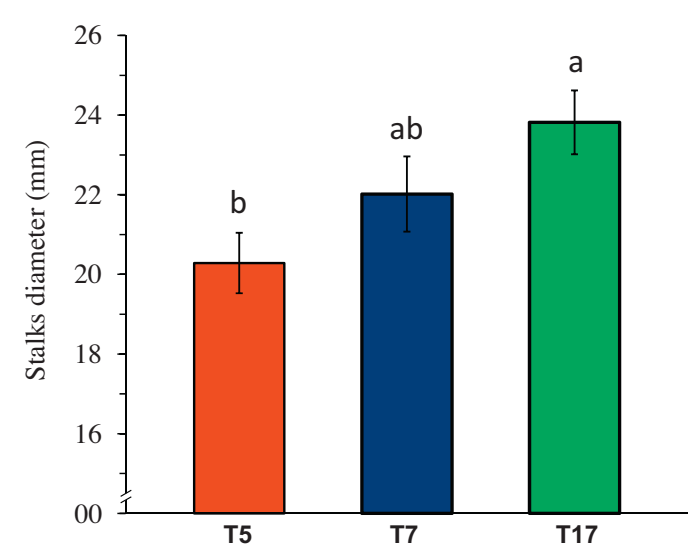

Fig. 6. Diameter of corn (Zea mays L.) plant stalks sowed with a seeder equipped with fixed shank openers working at $0.05 \mathrm{~m}$ (T5), $0.07 \mathrm{~m}$ (T7) and $0.17 \mathrm{~m}$ (T17) depth, in a Ferralic Nitisol (Rhodic). Vertical bars represent the standard deviation in relation to the average. The same letter not differ among themselves regarding the Tukey test at $5 \%$ probability. 
Table 2

Root dry matter mass of corn plants sowed with a seeder equipped with fixed shank openers working at $0.05 \mathrm{~m}$ (T5), $0.07 \mathrm{~m}$ (T7) and $0.17 \mathrm{~m}$ (T17) depth in a Ferralic Nitisol (Rhodic).

\begin{tabular}{|c|c|c|c|c|c|c|c|}
\hline \multirow{2}{*}{$\begin{array}{l}\text { Layer } \\
\text { (m) }\end{array}$} & \multicolumn{4}{|c|}{ Root dry matter mass } & \multicolumn{3}{|c|}{ Root dry matter mass } \\
\hline & $\begin{array}{l}\text { T5 } \\
\text { (g per }\end{array}$ & $\begin{array}{l}\mathrm{T7} \\
\mathrm{nt})\end{array}$ & T17 & $\begin{array}{l}\text { CV } \\
(\%)\end{array}$ & $\begin{array}{l}\text { T5 } \\
(\% \mathrm{pe}\end{array}$ & $\begin{array}{c}\mathrm{T} 7 \\
\text { yer) }\end{array}$ & T17 \\
\hline $0.00-0.05$ & $6.29 \mathrm{a}$ & $5.61 \mathrm{a}$ & $6.45 \mathrm{a}$ & 17.4 & 74 & 64 & 59 \\
\hline $0.05-0.17$ & $1.49 \mathrm{c}$ & $2.39 \mathrm{~b}$ & $3.79 \mathrm{a}$ & 13.4 & 17 & 27 & 35 \\
\hline $0.17-0.30$ & $0.73 \mathrm{a}$ & $0.79 \mathrm{a}$ & $0.63 \mathrm{a}$ & 8.9 & 9 & 9 & 6 \\
\hline Total & $8.52 \mathrm{~b}$ & $8.80 \mathrm{~b}$ & $10.87 \mathrm{a}$ & 9.5 & 100 & 100 & 100 \\
\hline
\end{tabular}

Average followed by the same letter horizontally, they do not differ among themselves regarding the Tukey test at 5\% probability.

\subsection{Development of corn plants}

The better soil physical conditions, provided by the opener action, influenced the development of corn plants. The corn plant stalk diameter, for T17 treatment, increased in comparison to the corn plants for T5 and T7 treatment (Fig. 6). The thickness of these plants stalk, is probably due to better soil physical conditions at the layer $0.07-0.17 \mathrm{~m}$. Freddi et al. (2009) observed that with the reduction in penetration resistance in the layer $0.0-0.20 \mathrm{~m}$ there was a linear increase in stalk diameter and the corn plant dry matter mass in an Oxisol.

The corn plant root development was also influenced by the depth of the seeder opener action. It can be seen, from Table 2 that for T17, the root dry matter mass, per corn plant, was higher than that of the corn plant root dry matter mass for T5 and T7. Thus, it seems that the deepening of the openers resulted in plant development with higher root dry matter mass. The increase in root dry matter mass per plant is due to the increase in root dry matter mass in the $0.05-0.17 \mathrm{~m}$ layer, due to the decrease in soil compaction in this layer, provided by the seeder opener action. Only in this layer $(0.05-0.17 \mathrm{~m})$ there was statistical difference, for this variable, between T17 treatment and T5 and T7 treatments.

In relation to root dry matter mass quantified in layer 0.0$0.30 \mathrm{~m}$ (total quantified), in the layer $0.0-0.05 \mathrm{~m}$, there was a concentration of $74-64 \%$ of root dry matter mass quantified, for T5 and T7, respectively. In the layer $0.05-0.17 \mathrm{~m}$, these percentages do not go beyond $17 \%$ (T5) and $27 \%$ (T7). This clearly indicates that the deepening of the plant root system in NT areas is limited by the soil subsurface layer compaction. According to Imhoff et al. (2010), with penetration resistance values equal to $3.0 \mathrm{MPa}$, (similar to the value obtained in this study $-0.07-0.17 \mathrm{~m}$ layer), the corn plant root growth is severely affected. When the root system reaches the compacted layer, root proliferation occurs in the topsoil (Rosolem et al., 1998). However, the compacted soil layer $(0.07-0.20 \mathrm{~m})$ limits the water capillary from the subsoil (below the compacted layer) to the topsoil layer (0.0-0.07 m) (Lipiec et al., 2003), where the root system is concentrated (Table 2). Thus, the absorption of water and nutrients is impaired by plants (Batey and McKenzie, 2006) and water stress manifests itself, even in short periods of drought, which aggravates the effects of drought and reduces crop yields (Buttery et al., 1998; Hamza and Anderson, 2005; Chen and Weil, 2011). The deepening of the root system, therefore, can reduce the risk of crop losses caused by drought.

The results obtained in this study reinforce the idea of Denardin et al. (2008). These authors related that the use of seeders equipped with openers working only up to $0.10 \mathrm{~m}$ depth, favors the concentration of the crop root systems in the first few centimeters of the soil under NT. In this sense, the deepening the fixed shanks openers (T17) promoted the corn plant root development in the layer $0.05-0.17 \mathrm{~m}$ (Table 2$)$. In this layer $(0.05-0.17 \mathrm{~m})$, the root concentration changed from $17 \%$ in $\mathrm{T} 5$ to $35 \%$ in T17. According to Vepraskas (1994), with increasing volume of macropores it may
Table 3

Root density and root length density of corn plants sowed with a seeder equipped with fixed shank openers working at $0.05 \mathrm{~m}$ (T5), $0.07 \mathrm{~m}$ (T7) and $0.17 \mathrm{~m}$ (T17) depth in a Ferralic Nitisol (Rhodic).

\begin{tabular}{|c|c|c|c|c|}
\hline \multirow{2}{*}{$\begin{array}{l}\text { Layer } \\
\mathrm{m}\end{array}$} & \multicolumn{3}{|c|}{ Treatment } & \multirow{2}{*}{$\begin{array}{l}\text { CV } \\
\%\end{array}$} \\
\hline & T5 & $\mathrm{T} 7$ & $\mathrm{~T} 17$ & \\
\hline \multicolumn{5}{|c|}{ Root density $\left(\mathrm{kg} \mathrm{m}^{-3}\right)$} \\
\hline $0.00-0.05$ & $4.20 \mathrm{a}$ & $3.58 \mathrm{a}$ & $4.30 \mathrm{a}$ & 19.8 \\
\hline $0.05-0.17$ & $0.40 \mathrm{~b}$ & $0.70 \mathrm{ab}$ & $1.01 \mathrm{a}$ & 25.1 \\
\hline $0.17-0.30$ & $0.20 \mathrm{ab}$ & $0.21 \mathrm{a}$ & $0.17 \mathrm{~b}$ & 8.9 \\
\hline Total & $0.95 \mathrm{~b}$ & 0.98 ba & $1.21 \mathrm{a}$ & 9.9 \\
\hline \multicolumn{5}{|c|}{ Root length density $\left(\mathrm{cm} \mathrm{cm}^{-3}\right)$} \\
\hline $0.00-0.05$ & 5.69 a & $3.77 \mathrm{a}$ & $5.64 \mathrm{a}$ & 23.2 \\
\hline $0.05-0.17$ & $1.28 \mathrm{a}$ & $2.17 \mathrm{a}$ & $2.36 \mathrm{a}$ & 26.8 \\
\hline $0.17-0.30$ & $1.41 \mathrm{a}$ & $1.54 \mathrm{a}$ & $1.29 \mathrm{a}$ & 10.2 \\
\hline Total & $2.07 \mathrm{a}$ & $2.17 \mathrm{a}$ & $2.46 \mathrm{a}$ & 9.4 \\
\hline
\end{tabular}

Average followed by the same letter horizontally, they do not differ among themselves regarding the Tukey test at $5 \%$ probability.

occur increase of corn root. Bengough et al. (2011) argue that the rate of corn root elongation decreases in response to increasing penetrometer resistance. Therefore, the reduced resistance to penetration and the increase in aeration porosity in the soil subsurface layer promoted a deeper growth of the corn root system.

The corn plant root density was also significantly higher in T17, in comparison to the treatment T5 and T7 (Table 3). With the opener deeper action, the root density values changed from 0.95 and $0.98 \mathrm{~kg} \mathrm{~m}^{-3}$ in $\mathrm{T} 5$ and $\mathrm{T} 7$, respectively, to $1.21 \mathrm{~kg} \mathrm{~m}^{-3}$ in T17. Similarly, in the 0.05-0.17 m layer, the corn plant root length density changed from $1.28 \mathrm{~cm}$ root per soil cubic $\mathrm{cm}$ and $2.17 \mathrm{~cm}$ root per soil cubic $\mathrm{cm}$, respectively in $\mathrm{T} 5$ and $\mathrm{T} 7$, to $2.36 \mathrm{~cm}$ root per soil cubic cm in T17 (Table 3). The corn plant root length density values, quantified in this study, were similar to the values obtained by Ivo and Mielniczuk (1999). According to these authors, the root length density of corn plants grown in soil under NT were 4.2; 1.8 and $1.8 \mathrm{~cm}$ root per soil cubic $\mathrm{cm}$, respectively in the $0-0.05 \mathrm{~m}$; $0.10-0.15 \mathrm{~m}$; and $0.25-0.35 \mathrm{~m}$ layers. However, our results were higher than those observed to Foloni et al. (2003) and Ji et al. (2013).

The corn plant higher root density and the corn plant higher root length is due to the better root development in the soil layer between 0.05 and $0.17 \mathrm{~m}$ (Table 3 ), the place where the seeder deep action openers (T17) acted relieving soil compaction. The highest concentration of the plants root system between 0.05 and $0.17 \mathrm{~m}$ depth in T17 compared with T7 (Table 3), however, resulted in significantly lower root density at $0.17-0.30 \mathrm{~m}$ layer in T17 compared with treatment T7.

\subsection{Soil compaction relief and plant soil interactions}

The root development intensification due to the soil compaction mitigation, result of the seeders openers' action, contributed to better physical conditions of the soil in the mobilized layer. The use of this kind of seeders not only breaks the compacted soil mass, through the opener mechanical action, but also lays seeds (approximately at $0.05 \mathrm{~m}$ depth) that will originate plants deeper in the mobilized soil, developing roots that will occupy the space generated by the openers mechanical action. This might delay the soil natural reconsolidation process (Raper et al., 2005) and stimulate aggregation in the subsurface layer of the soil under NT (Calegari et al., 2008; Guedes Filho et al., 2013). According to Raper et al. (2005), narrower zone of loosened soil such as provided by a subsoiler, may have offered roots a downward path to grow while limiting reconsolidation from vehicle traffic. 
According to Horn and Peth (2009), the soil aggregation process first undergoes mechanical stress and, later on, improvement of the aggregation through the biological activity. If the soil physical improvement allows deepening of the species root system and the roots contribute to the soil structure maintenance and restructuring (Calegari et al., 2008; Martins et al., 2009), the use of a seeder equipped with fixed shanks openers working at $0.17 \mathrm{~m}$ deep, has the potential to mitigate soil compaction under NT. The efficiency of this action, however, depends on the no-till system considering the diversification of crops (Derpsch et al., 2010; Calegari et al., 2008). The implementation of species with an aggressive root system such as corn, throughout the crop years, can increase the soil organic carbon, due to the incorporation of organic matter via root system (Allmaras et al., 2004; Neumann and Romheld, 2001). The arrival of organic matter to the soil, in amount, quality and frequency suitable to the biological demand of the soil, together with the crop diversification, involving plants that have intense root system, therefore, might promote effective remedy to the soil compaction (Colonego and Rosolem, 2010; Chen and Weil, 2011).

The effectiveness of the drill seeder equipped with shank openers in the physical soil improvement also depends on the soil moisture at the period of sowing as well as on the width of the shank. In this study, the seeding operations were performed when the soil moisture was near the point of friability - the soil retains the slightly adhered particles and is soft; when compressed, before disruption, the soil presents a slight deformation and crack signals; the material resultant from the disruption is formed mainly by aggregates, which allows the reconstruction of the soil clod (Reichert et al., 2010). According to Baver et al. (1973), this state of humidity is ideal for carrying out this type of practice. The thickness of the shank was $15 \mathrm{~mm}$, which, from one side, allowed the compacted soil to be broken in the row, while, in the other side, let the crop residues to be retained on the soil surface (Fig. 1a). The employment of the drill seeder equipped with fixed shanks openers acting in depth, thus do not mischaracterize the no tillage system (Franchini et al., 2012.), because it keeps the cultural remains at the soil surface, mobilizes the soil only in the row; and with crop diversification, leaves the soil permanently covered.

Furthermore, the deepening of the crop root system with the use of a seeder equipped with deep action openers $(0.17 \mathrm{~m})$, represented in this study by the corn crop (Tables 2 and 3), can result in higher volume of soil explored by the root system and, consequently, higher absorption of the soil solution, which contains water and nutrients, fundamental to the plant development and productivity. The use of a seeder equipped with deep action openers, for NT, therefore, can decrease risk of crop losses, when there are short periods of drought.

The positive effects deriving from the use of the seeder equipped with fixed shank operating at higher depths on the physical improvement of the soil and hence the development of crops root system in NT are evident. In this study, however, the possible negative effects arising from this practice have not been studied. According to Franchini et al. (2012), the removal of intensive soil tillage results in the preservation of soil biopores, which are continuous and stable. For this reason, in soil under NT, microbial activity and continuity of the pores are high (Tavares Filho et al., 2012). To Horn (2004), the better functioning of pore systems can be obtained under a continuously applied system of conservation tillage. Therefore, considering that the soil movement by the shank can have a negative effect on the continuity of soil pores, further studies to assess possible negative effects of this practice should be developed.

\section{Conclusions}

When using a seeder equipped with shank openers working up to $0.07 \mathrm{~m}$, the soil presented, in the $0-0.07 \mathrm{~m}$ layer, a high macroporosity, low resistance to penetration, and low bulk density, keeping $74 \%$ of the corn root; whereas the $0.07-0.17 \mathrm{~m}$ layer presented low macroporosity, high resistance to penetration, high bulk density, and high degree of compactness, keeping $17 \%$ of the corn root. The deepening of the plant root system in NT areas, therefore, is limited by the soil subsurface layer compaction.

The use of a seeder equipped with fixed shanks openers working at $0.17 \mathrm{~m}$ depth: (i) improved macroporosity, total porosity and availability of water to the plants and reduced penetration resistance, bulk density, and degree of compactness in the 0.07-0.17 m layer; (ii) promoted development of corn plants with greater stalk diameter, greater root dry mater mass, and greater root length; and (iii) improved the development of corn plant root system in $0.05-0.17 \mathrm{~m}$ layer of a soil under NT.

Our results showed that the use of a seeder equipped with fixed shanks openers working at $0.17 \mathrm{~m}$ depth presents high potential to improve soil physical root growth conditions on clay soils under NT. This kind of seeder can break the compacted soil layer and keeps the crop residues on the top soil. The efficiency of this action, however, depends on the model of crop production, which should consider the diversification of crops, cultivation of species with different root systems and with high potential to produce large amounts of biomass.

\section{References}

Allmaras, R.R., Linden, D.R., Clapp, C.E., 2004. Corn-residue transformations into root and soil carbon as related to nitrogen, tillage and stover management. Soil Sci. Soc. Am. J. 68, 1366-1375.

Altikat, S., Celik, A., 2011. Effects of different furrow openers, covering components and forward speeds in no till seeders on the soil surface roughness. Univ. J. Inst. Sci. Technol. 1, 85-90.

Baker, C.J., 1976. Experiments relating to techniques for direct drilling of seeds into untilled dead turf. J. Agric. Eng. Res. 21, 133-134.

Batey, T., 2009. Soil compaction and soil management: a review. Soil Use Manage. 25, 335-345.

Batey, T., McKenzie, D.C., 2006. Soil compaction: identification directly in the field. Soil Use Manage. 22, 123-131.

Baver, L.D., Gardner, W.H., Gardener, W.R., 1973. Fisica of soils. México 529p.

Bengough, A.G., McKenzie, B., Hallett, M., Valentine, P.D., 2011. Root elongation, water stress, and mechanical impedance: a review of limiting stresses and beneficial root tip traits. J. Exp. Bot. 62, 59-68.

Bohm, W., 1979. Methods of Studying Root Systems. Springer-Verlag, New York.

Buttery, B.R., Tan, C.S., Drury, C.F., Park, S.J., Armstrong, R.J., Park, K.Y., 1998. The effects of soil compaction: soil moisture and soil type on growth and nodulation of soybean and common bean. Can. J. Plant Sci. 78, 571-576.

Calegari, A., Hargrove, W.L., Rheinheimer, D.S., Ralisch, R., Tessier, D., Tourdonnet, S., Guimarães, M.F., 2008. Impact of long-term no-tillage and cropping system management on soil organic carbon in an oxisol: a model for sustainability. Agron. J. 100, 1013-1019.

Casão Junior, R., Araújo, A.G., Llanillo, R.F., 2012. No-till in South Brazil: Factors that Facilitated the Evolution of the System and the Development of Conservation Mechanization. IAPAR, Londrina 77p.

Chaudhuri, D, 2001. Performance evaluation of various types of furrow openers on seed drills: a review. J. Agric. Eng. Res. 79, 125-137.

Chen, G., Weil, R.R., 2011. Root growth and yield of maize as affected by soil compaction and cover crops. Soil Till. Res. 117, 17-27.

Colonego, J.C., Rosolem, C.A., 2010. Soybean root growth and yield in rotation with cover crops under chiseling and no-till. Eur. J. Agron. 33, 242-249.

Damora, D., Pandey, K.P., 1995. Evaluation of performance of furrow openers of combined seed and fertilizer drills. Soil Till. Res. 34, 127-139.

Denardin, J.E., Kochhann, R.A., Bacaltchuk, B., Sattler, A., Denardin, N.D'A., Faganello, A., Wiethölter, S., 2008. No-till system: factor of Brazilian tropical agriculture potential. In: Albuquerque, A.C.S., Silva, A.G. (Eds.), Tropical Agriculture: Four Decades of Technological, Institutional and Political Innovation. Embrapa Technological Information, Brasília 1251-1273pp.

Derpsch, R., Friedrich, T., Kassam, A., Hongwen, L., 2010. Current status of adoption of no-till farming in the world and some of its main benefits. Int. J. Agric. Biol. Eng. 3, 1-26.

Donagema, G.K., Campos, D.V.B., Calderano, S.B., Teixeira, W.G., Viana, J.H.M., 2011. Manual of Soil Method Analysis, second ed. Embrapa Solos, Rio de Janeiro. 
Farooq, M., Flower, K.C., Jabran, K., Wahid, A., Siddique, K.H.M., 2011. Crop yield and weed management in rainfed conservation agriculture. Soil Till. Res. 117, $172-183$.

Foloni, J.S.S., Calonego, J.C., Lima, S.L., 2003. Effect of soil compaction on shoot and root growth of maize cultivars. Braz. J. Agric. Res. 38, 947-953.

Franchini, J.C., Debiasi, H., Balbinot Junior, A.A., Tonon, B.C., Farias, J.R.B., Oliveira, M. C.N., Torres, E., 2012. Evolution of crop yields in different tillage and cropping systems over two decades in southern Brazil. Field Crops Res. 137, 178-185.

Freddi, O.S., Centurion, J.F., Duarte, A.P., Leonel, C.L., 2009. Soil compaction and production of corn cultivars in an oxisol. I? plant characteristics, soil and S index. Braz. J. Soil Sci. 33, 793-803.

Gee, G.W., Or, D., 2002. Particle-size analysis. In: Dane, J.H., Topp, G.C. (Eds.), Methods of Soil Analysis. Soil Science Society of America, Madison, Wisconsin, USA pp. 255-293.

Genro Junior, S.A., Reinert, D.J., Reichert, J.M., 2004. Temporal variation of soil penetration resistance in a clayey oxisol under no-tillage and crop rotation. Braz. J. Soil Sci. 28, 477-484.

Guedes Filho, O., Silva, A.P., Giarola, N.F.B., Tormena, C.A., 2013. Structural properties of the soil seedbed submitted to mechanical and biological chiseling under notillage. Geoderma 204-205, 94-101.

Hakansson, I., Lipiec, J., 2000. A review of the usefulness of relative bulk density values in studies of soil structure and compaction. Soil Till. Res. 53, 71-85.

Hamza, M.A., Anderson, W.K., 2005. Soil compaction in cropping systems: a review of the nature, causes and possible solutions. Soil Till. Res. 82, 121-145.

Horn, R., 2004. Time dependence of soil mechanical properties and pore functions for arable soils. Soil Sci. Soc. Am. J. 68, 1131-1137.

Horn, R., Peth, S., 2009. Soil structure formation and management effects on gas emission. Biologia 64, 449-453.

Hubbard, R.K., Hargrove, W.L., Lowrance, R.R., Williams, R.G., Mullinix, B.G., 1994. Physical properties of a clayey coastal plain soil as affected by tillage. J. Soil Water Conserv. 49, 276-283.

Imhoff, S., Kay, B.D., Silva, A.P., Hajabbasi, M.A., 2010. Evaluating responses of maize (Zea mays L.) to soil physical conditions using a boundary line approach. Soil Till. Res. 106, 303-310.

Ivo, W.M.P.M., Mielniczuk, J., 1999. Influence of soil structure on the distribution and morphology of corn roots under three tillage methods. Braz. J. Soil Sci. 23, $135-143$.

Ji, B., Zhao, Y., Um, X., Liu, K., Li, C., 2013. Effects of tillage on soil physical properties and root growth of maize in loam and clay in central China. Plant Soil Environ. 59, 295-302.

Jorge, L.A.C., Rodrigues, A.F.O., 2008. Safira: System of Root and Fibrous Analysis. Embrapa Agriculture Instrumentation, São Carlos.

Kaspar, T.C., Brown, H.J., Kassmeyer, E.M., 1991. Corn root distribution as affected by tillage, wheel traffic, and fertilizer placement. Soil Sci. Soc. Am. J. 55, 1390-1394.

Lahmar, R., 2010. Adoption of conservation agriculture in Europe: lessons of the KASSA project. Land Use Policy 27, 4-10.

Lipiec, J., Arvidsson, J., Murer, E., 2003. Review of modelling crop growth: movement of water and chemicals in relation to topsoil and subsoil compaction. Soil Till. Res. 73, 15-29.

Lipiec, J., Horn, R., Pietrusiewicz, J., Siczek, A., 2012. Effects of soil compaction on root elongation and anatomy of different cereal plant species. Soil Till. Res. 121, 74-81.

Martins, M.R., Corá, J.E., Jorge, R.F., Marcelo, A.V., 2009. Crop type influences soil aggregation and organic matter under no-tillage. Soil Till. Res. 104, 22-29.

Neumann, G., Romheld, V., 2001. The release of root exudates as affected by the plant's physiological status. In: Pinton, R., Varanini, Z., Nannipieri, P. (Eds.), The
Rhizosphere. Biochemistry and Organic Substances at the Soil Plant Interface. Marcel Dekker, New York p. 41-93.

Nimer, E., 1989. Climatology of Brazil. IBGE, Rio de Janeiro 442p.

Nosalewicz, A., Lipiec, J., 2014. The effect of compacted soil layers on vertical root distribution and water uptake by wheat. Plant Soil 375, 229-240.

Nunes, M.R., Denardin, J.E., Faganelo, A., Pauletto, E.A., Pinto, L.F.S., 2014a. Effect of seed drill with fixed shanks for deep action in soil under no-till. Braz. J. Soil Sci. 38, 627-638.

Nunes, M.R., Pauletto, E.A., Denardin, J.E., Faganelo, A., Pinto, L.F.S., Scheunemann, T., 2014b. Persistence of chiseling effects on the compaction of a Nitisol under notill in a humid subtropical region. Braz. J. Agric. Res. 49, 531-539.

Raper, R.L., Schwab, E.B., Balkcom, K.S., Burmester, C.H., Reeves, D.W., 2005. Effect of annual, biennial, and triennial in-row subsoiling on soil compaction and cotton yield in Southeastern U.S. silt loam soils. Am. Soc. Agric. Eng. 21, 337-343.

Reichert, J.M., Suzuki, L.E.A.S., Reinert, D.J., Horn, R., Hakansson, I., 2009. Reference bulk density and critical degree-of-compactness for no-till crop production in subtropical highly weathered soils. Soil Till. Res. 102, 242-254.

Reichert, J.M., Reinert, D.J., Suzuky, L.A.S., Horn, R., 2010. Soil mechanics. In: van Lier Q.J. (Ed.), Soil Physics. Brazilian Soil Science Society 29-102pp.

Ritchie, S.W., Hanway, J.J., 1993. How a Corn Plant Develops. Iowa University of Science and Technology, Cooperative Extension Service, Ames.

Ros, V.V., Souza, C.M.A., Vitorino, A.C.T., Rafull, L.Z.L., 2011. Oxisol resistance to penetration in no-till system after sowing. Braz. J. Agric. Eng. Environ. 31 $1104-1114$.

Rosolem, C.A., Schiochet, M.A., Souza, L.S., Whitacker, J.P.T., 1998. Root growth and cotton nutrition as affected by liming and soil compaction. Com. Soil Sci. Plant Anal. 29, 169-177.

Shipitalo, M.J., Protz, R., 1987. Comparison of morphology and porosity of a soil under conventional and zero tillage. Can. J. Soil Sci. 67, 445-456.

Silva, A.P., Ball, B.B., Tormena, C.A., Giarola, N.F.B., Guimarães, R.M.L., 2014a. Soil structure and greenhouse gas production differences between row and interrow. Sci. Agric. 71, 157-162.

Silva, A.P., Babujia, L.C., Franchini, J.C., Ralisch, R., Hungria, M., Guimarães, M.F. 2014b. Soil structure and its influence on microbial biomass in different soil and crop management systems. Soil Till. Res. 142, 42-53.

Soane, B.D., 1990. The role of organic matter in soil compactibility: a review of some practical aspects. Soil Till. Res. 16, 179-201.

Suzuki, L.E.A.S., Reichert, J.M., Reinert, D.J., 2013. Degree of compactness: soil physical properties and yield of soybean in six soils under no-tillage. Soil Res. 51, $311-321$.

Tavares Filho, J., Ralisch, R., Guimarães, M.F., Medina, C.C., Balbino, L.C., Neves, C.S.V. J., 1999. Cultural profile methodology for soil physical evaluation under tropical conditions. Braz. J. Soil Sci. 23, 393-399.

Tavares Filho, J., Guimarães, M.F., Curmi, P., Tessier, D., 2012. Physical properties of an Alfisol and no-till soybean yield. Braz. J. Soil Sci 36, 253-260.

Tormena, C.A., Silva, A.P., Libardi, P.L., 1999. Soil physical quality of a Brazilian Oxisol under two tillage systems using the least limiting water range approach. Soil Till. Res. 52, 223-232.

Tormena, C.A., Silva, A.P., Imhoff, S.C., Dexter, A.R., 2008. Quantification of the soil physical quality of a tropical Oxisol using the S index. Sci. Agric. 65, 56-60.

United States Departmentof Agriculture (USDA), 2012. Soil Taxonomy. USDA-NRCS, Washington, DC, USA.

Veiga, M., Horn, R., Reinert, D.J., Reichert, J.M., 2007. Soil compressibility and penetrability of an Oxisol from Southern Brazil, as affected by long-term tillage systems. Soil Till. Res. 92, 104-113.

Vepraskas, M.J., 1994. Plant response mechanisms to soil compaction. In: Wilkinson, R. (Ed.), Plant Environment Interactions. M. Dekker, New York, pp. 263-287. 